\title{
KLAUSIMŲ EILIŠKUMO EFEKTAI VERTINANT PRIVALOMĄSIAS IR APSAKOMĄSIAS SOCIALINES NORMAS
}

\author{
Mykolas Simas Poškus \\ Mykolo Romerio universiteto \\ Socialinių technologijų fakulteto \\ Psichologijos institutas \\ Ateities g. 20, LT-08303 Vilnius, Lietuva \\ Telefonas (+370 5) 2714620 \\ El.paštas: mykolas.simas@gmail.com
}

Pateikta 2014 m. kovo 21 d., parengta spausdinti 2014 m. lapkričio 17 d.

doi:10.13165/SMS-14-6-3-05

Anotacija. Tyrimuose, kuriuose socialinèms normoms įvertinti naudojami klausimynai, ne visada ìvertinami klausimu eiliškumo efektai - atsakymu pokyčiai, priklausantys nuo klausimo padeties klausimyne. Šiame tyrime analizuoti klausimu eiliškumo efektai, galintys pasireikšti, vertinant socialines normas. Keltas tikslas išsiaiškinti klausimu eiliškumo efektų dèsningumus, pasireiškiančius tiriant apsakomąsias bei privalomąsias socialines normas.

Tyrimo rezultatai atskleide, jog socialiniu normu ìverčiai skiriasi priklausomai nuo i skirtingas normas nukreiptu teiginiu padeties klausimyne. Aptikta, jog apsakomuju normu vertinimai yra jautrūs klausimu eiliškumui: pirmiau pateikus teiginius, nukreiptus i privalomasias normas, apsakomosios normos suvokiamos kaip labiau nutolusios nuo privalomuju. Kita vertus, aptikta, jog privalomuju normu vertinimai yra gana atsparūs eiliškumo efektams ir ju ịverčiai iš esmès nesiskiria priklausomai nuo padeties klausimyne.

Socialinių mokslų studijos / Societal Studies

(C) Mykolo Romerio universitetas, 2014

(C) Mykolas Romeris University, 2014
ISSN 2029-2244 (online)

http://www.mruni.eu/lt/mokslo_darbai/SMS/ http://www.mruni.eu/en/mokslo_darbai/SMS/ 
Tyréjams, norintiems sumažinti klausimu eiliškumo efektus socialiniu normu tyrimuose, rekomenduojame klausimynu teiginius, orientuotus į privalomąsias ir apsakomąsias normas, pateikti atsitiktine tvarka.

Reikšminiai žodžiai: privalomosios normos, apsakomosios normos, klausimu eiliškumas.

\section{Ivadas}

Apsakomosios ir privalomosios socialinės normos. Skiriamos dviejų tipu socialinès normos: apsakomosios (angl. descriptive norms) ir privalomosios (angl. injunctive norms arba prescriptive norms $)^{1}$. Apsakomosios normos iqvardina stebimą būdingą daugumos elgseną tam tikroje situacijoje. Šios normos padeda žmogui suprasti, kokia elgsena yra paplitusi ir efektyvi, kadangi šios normos susiformuoja stebint aplinkinių elgseną ir matant šios elgsenos pasekmes. Remdamasis apsakomosiomis normomis, asmuo gali planuoti ir realizuoti savo tikslus, realiai ịvertinti vienų ar kitų veiksmų pasekmes bei naudą ${ }^{2} 4567$.

Privalomosios normos nusako tai, ką žmogus suvokia kaip jo socialinëje grupejje priimtiną ir pageidautiną elgseną ${ }^{8}$. Šios normos reguliuoja žmogaus elgseną suteikdamos aiškias ribas, kokia elgsena yra skatintina ar baustina. Privalomosios normos apima visuomenés moralines nuostatas, tradicijas, taisykles, ịstatymus, susitarimus ir kita.

Tiek apsakomosios, tiek privalomosios normos turi įtakos žmogaus elgsenai, tačiau apsakomosios normos turi ịtakos nepriklausomai, ar jos nusako pageidautiną, ar nepageidautiną elgseną. Kitaip tariant, žmonès linkę elgtis taip, kaip galvoja, jog

1 Brauer, M.; Chaurand, N. Descriptive Norms, Prescriptive Norms, and Social Control: An Intercultural Comparison of People's Reactions to Uncivil Behaviors. European Journal of Social Psychology. 2010, 40(3): 490-499.

Ibid.

3 Cialdini, R. B.; Reno, R. R.; Kallgren, C. A. A Focus Theory of Normative Conduct: Recycling the Concept of Norms to Reduce Littering in Public Places. Journal of Personality and Social Psychology. 1990, 58(6): 1015-1026.

4 Gerber, A. S.; Rogers, T. Descriptive Social Norms and Motivation to Vote: Everybody's Voting and so Should You. The Journal of Politics. 2009, 71(1): 178-191.

5 Reno, R. R.; Cialdini, R. B.; Kallgren, C. A. The Transsituational Influence of Social Norms. Journal of Personality and Social Psychology. 1993, 64(1): 104-112.

6 Smith, J. R.; Louis, W. R. Do as We Say and as We Do: The Interplay of Descriptive and Injunctive Group Norms in the Attitude-Behaviour Relationship. British Journal of Social Psychology. 2008, 47(4): 647-666.

7 White, K. M.; Smith, J. R.; Terry, D. J.; Greenslade, J. H.; McKimmie, B. M. Social Influence in the Theory of Planned Behaviour: The Role of Descriptive, Injunctive, and In-Group Norms. British Journal of Social Psychology. 2009, 48(1): 135-158.

Reno, R. R.; Cialdini, R. B., Kallgren, C. A., supra note 5. 
elgiasi dauguma, net jei tai prieštarauja privalomosioms normoms ${ }^{9}{ }^{10}$. Tokią tendenciją galima paaiškinti iš evoliucinès perspektyvos: suvokimas, jog viena ar kita socialiai nepageidautina elgsena yra paplitusi, motyvuoja elgtis pagal daugumos pavyzdi, siekiant naudos, kurią ši elgsena suteikia. Kita vertus, suvokimas, jog tam tikros normos yra visuotinai laikomasi, skatina jos laikytis, vengiant žalos, kurią atneštų normos pažeidimas. R. B. Cialdini ir kiti ${ }^{11}$ teigia, jog normų laikomasi, nes tai sumažina kognityvines pastangas priimant sprendimus.

Normų suaktyvinimas. Normos daugiausia ịtakos turi tada, kai jos yra suaktyvinamos žmogaus sąmonèje $e^{12} 1314 \quad 15$. Kitaip tariant, žmonès labiau linkę laikytis taisyklių, kai apie jas galvoja, - vadovavimuisi normomis ịtakos turi tam tikra parengtis (angl. priming). R. B. Cialdini ir kiti ${ }^{16}$, tirdami normų ịtaką šiukšlinimui, aptiko neintuityvų dèsningumą: kai šiukšlinimas yra aiškiai išreikštas kaip apsakomoji norma (aplinkoje yra daug šiukšlių), žmonès labiau linksta šiukšlinti, tačiau mažiausias šiukšlinimas stebimas tada, kai aplinkoje yra vienintelè šiukšlè - vienos šiukšlès atveju žmonès linkę šiukšlinti mažiau negu visiškai švarioje aplinkoje. Kai stebimas pavienis normos pažeidimas, jis galimai suaktyvina šią normą, apie kurią, nesant pažeidimo, nebūtų aktyviai galvojama. Šiukšlinimas taip pat sumažèja, jei prišiukšlintoje aplinkoje privalomoji norma nešiukšlinti yra iškeliama ị sąmonę, pavyzdžiui, praeivis pakelia šiukšlę ${ }^{17}$. Tai rodo, jog tam tikrų normų iškèlimas ị sąmonę iš esmès gali turèti įtakos elgsenai, todèl - ir klausimynų pildymui.

Klausimų eiliškumo efektų problema normų tyrimuose. Tai, jog normos daugiausia įtakos turi tada, kai yra sužadinamos, turi tam tikrų implikacijų normų bei nuostatų tyrimams. Tai ypač svarbu tyrimuose, kuriuose naudojamos apklausos raštu, kur tyrimo dalyviams tenka deklaruoti savo nuostatas ị tam tikrą elgseną, normas, atpasakoti savo elgseną ar daryti moralinius sprendimus. Dažniausiai normos tiriamos gana neittraukiančiais savistatos klausimynais, kurie nèra emociškai stimuliuojantys,

9 Croson, R.; Handy, F.; Shang, J. Keeping Up With the Joneses. The Relationship of Perceived Descriptive Social Norms, Social Information, and Charitable Giving. Nonprofit Management \& Leadership. 2009, 19(4): 467-489.

10 Gerber, A. S.; Rogers, T., supra note 4.

11 Cialdini, R. B.; Reno, R. R.; Kallgren, C. A., supra note 3.

12 Griskevicius, V.; Cialdini, R. B.; Goldstein, N. J. Social Norms: An Underestimated and Underemployed Lever for Managing Climate Change. International Journal of Sustainability Communication. 2008, 3: 5-13.

13 Kallgren, C. A.; Reno, R. R.; Cialdini, R. B. A Focus Theory on Normative Conduct: When Norms Do and Do Not Affect Behavior. Personality and Social Psychology Bulletin. 2000, 26(8): 1002-1012.

14 Melnyk, V.; van Herpen, E.; Fischer, A. R. H.; van Trij, H. C. M. To Think of not to Think: The Effect of Cognitive Deliberation on the Influence of Injunctive Versus Descriptive Social Norms. Psychology \& Marketing. 2011, 28(7): 709-729.

15 Smith, J. R.; Louis, W. R., supra note 6.

16 Cialdini, R. B.; Reno, R. R.; Kallgren, C. A., supra note 3.

17 Reno, R. R.; Cialdini, R. B.; Kallgren, C. A., supra note 5. 
kalbantys apie hipotetines situacijas, todèl atsakymai ị juos būna paremti daugiau samprotavimais, kurie nebūtinai atspindi realią žmogaus elgseną ${ }^{18}$. Viena ar kita ị sąmonę iškelta mintis gali turèti neprognozuojamos įtakos klausimyno pildymui. Todèl dera atkreipti dèmesị $\mathfrak{i}$ tai, kaip atsakymus ị klausimus apie socialines normas bei jų laikymąsi gali nulemti pačių klausimų pateikimas.

Klausimų efektų būna labai įvairių. Žinoma, jog klausimo forma ${ }^{19}$, kontekstas ${ }^{20}$, klausimų eiliškumas ${ }^{21} 22$, taip pat ar klausimai užduodami žodžiu, ar raštu ${ }^{24}$, netgi klausimyno išvaizda, atsakymo laukų dydžiai ${ }^{25}$ ir atsakymų variantų padètis bei kryptis ${ }^{26}{ }^{27}$ gali turèti įtakos gautiems rezultatams. Visa tai itin svarbu tiriant normas, ypač kai žmonèms tenka atsakyti ị daug skirtingo pobūdžio klausimų, kurie tarpusavyje siejasi.

Vienas aiškiausių klausimų eiliškumo efektų pasireiškia tarp apibendrintų bei konkrečių klausimų. Manoma, kad konkretūs klausimai pažadina atsiminimus apie konkrečias situacijas, o vèliau, uždavus apibendrinto pobūdžio klausimą, šie pažadinti atsiminimai gali nulemti visumos suvokimąą ${ }^{29}$. Nustatyta, jog konkrečių klausimų

18 FeldmanHall, O.; Mobbs, D.; Evans, D.; Hiscox, L.; Navrady, L.; Dalgleish, T. What We Say and What We Do: The Relationship Between Real and Hypothetical Moral Choices. Cognition. 2012, 123(3): 434-441.

19 Kebbell, M. R.; Evans, L.; Johnson, S. D. The Influence of Lawyers' Questions on Witness Accuracy, Confidence, and Reaction Times and on Mock Jurors' Interpretation of Witness Accuracy. Journal of Investigative Psychology and Offender Profiling. 2010, 7(3): 261-271.

20 Blair, E.; Sudman, S.; Bradburn, N. M.; Stocking, C. How to Ask Questions about Drinking and Sex: Response Effects in Measuring Consumer Behavior. Journal of marketing Research. 1977, 14(3): 316-321.

21 Ramirez, I. L.; Straus, M. A. The Effect of Question Order on Disclosure in Intimate Partner Violence: An Experimental Test Using the Conflict Tactics Scales. Journal of Family Violence. 2006, 21(1): 1-9.

22 Schwarz, N.; Hippler, H-J. Subsequent Questions May Influence Answers to Preceding Questions in Mail Surveys. The Public Opinion Quarterly. 1995, 59(1): 93-97.

23 Siminski, P. Order Effects in Batteries of Questions. Quality \& Quantity. 2008, 42(4): 477-490.

24 Holbrook, A. L.; Krosnick, J. A.; Moore, D.; Tourangeau, R. Response Order Effects in Dichotomous Categorical Questions Presented Orally. The Impact of Question and Respondent Attributes. Public Opinion Quarterly. 2007, 71(3): 325-348.

25 Christian, L. M.; Dillman, D. A. The Influence of Graphical and Symbolic Language Manipulations on Responses to Self- Administered Questions. The Public Opinion Quarterly. 2004, 68(1): 57-80.

26 Chan, J. C. Response-Order Effects in Likert-Type Scales. Educational and Psychological Measurement. 1991, 51: 531-540.

27 McDermott, M. L.; Frankovic, K. A. The Polls - Review. Horserace Polling and Survey Method Effects: An Analysis of the 2000 Campaign. Public Opinion Quarterly. 2003, 67(2): 244-264.

28 Schröder, T.; Thagard, P. The Affective Meanings of Automatic Social Behaviors: Three Mechanismz That Explain Priming. Psychological Review. 2013, 120(1): 255-280.

29 Yang, S.; Wyckoff, L. A. Perceptions of Safety and Victimization: Does Survey Construction Affect Perceptions? Journal of Experimental Criminology. 2010, 6(3): 293-323. 
uždavimas lemia išsamesnius atsakymus ị vèlesnius atvirus klausimus, tačiau juose neretai atsispindi būtent anksčiau užduotų uždarų klausimų turinys ${ }^{30}$. Taip nutinka galimai dèl to, jog konkretūs klausimai, pateikti prieš apibendrintus, padaro vienokią ar kitokią informaciją labiau prieinamą respondentui ${ }^{31}$. Panašaus pobūdžio parengtis gali atsirasti ir tiriant socialines normas, kadangi privalomosios normos tam tikra prasme yra abstrakčios, ̣̦vardijančios idealią situaciją, o apsakomosios - konkrečios, ịvardijančios stebimą situaciją. Pirmiau pateikiami klausimai neišvengiamai sukuria kontekstą, kuriame vertinami vèlesni klausimai ${ }^{32}$, todèl svarbu suprasti, kokią ịtaką turi sužadintos vienokio pobūdžio normos, atsakant ị kitokio pobūdžio normų klausimus.

Tiriant normas savistatos būdu gali pasitaikyti situacijų, kuriose sunku pasakyti, ar duomenys nèra iškreipiami dèl pačio įvertinimo įrankio. Skaitant publikacijas, kuriose vertintos privalomosios bei apsakomosios normos, ne visada aišku, kokiu eiliškumu respondentams buvo pateikiami klausimai ir ar buvo stengiamasi kontroliuoti klausimų efektus 33343537 , neịvertinama kelių matavimų eiliškumo bei apskritai tyrimo konteksto, klausimų ịtaka ${ }^{38}$, netgi prie aiškiai pateiktos normoms matuoti skirtos anketos nèra užsimenama apie klausimų efektus ${ }^{39}$. Galiausiai, kai atsižvelgiama i galimus klausimų efektus, tai daroma gana paviršutiniškai ${ }^{40}$. Tai jokiu būdu nereiškia,

30 Willits, F. K.; Saltiel, J. Question Order Effects on Subjective Measures of Quality of Life. Rural Sociology. 1995, 60(4): 654-665.

31 Auh, S.; Salisbury, L. C.; Johnson, M. D. Order Effects in Customer Satisfaction Modeling. Journal of Marketing Management. 2003, 19(3-4): 379-400.

32 Scandell, D. J.; Wlazelek, B.; Bentelspacher, C. E.; Rees, K. S.; Thomas, S. L. Effects of Questionnaire Order on Self-Reported Sexual Behavior, Risk Perceptions, and Ratings of HIV and STD Protection Strategies. Journal of Psychology \& Human Sexuality. 2003, 15(1): 53-67.

33 Baumgartner, S. E.; Valkenburg, P. M.; Peter, J. The Influence of Descriptive and Injunctive Peer Norms on Adolescents' Risky Sexual Online Behavior. Cyberpsychology, Behavior, and Social Networking. 2011, 14(12): 75-758.

34 Neighbors, C.; Geisner, I. M.; Lee. C. M. Perceived Marijuana Norms and Social Expectancies Among Entering College Student Marijuana Users. Psychology of Addictive Behaviors. 2008, 23(3): 433-438.

35 Larimer, M. E.; Turner, A. P.; Mallett, K. A.; Geisner, I. M. Predicting Drinking Behavior and Alcohol-Related Problems Among Fraternity and Sorority Members: Examining the Role of Descriptive and Injunctive Norms. Psychology of Addictive Behavior. 2004, 18(3): 203-212.

36 Larimer, M. E.; Neighbors, C. Normative Misperception and the Impact of Descriptive and Injunctive Norms on College Student Gambling. Psychology of Addictive Behaviors. 2003, 17(3): 235-243.

37 Phua, J. J. The Reference Group Perspective for Smoking Cessation: An Examination of the Influence of Social Norms and Social Identification With Reference Groups on Smoking Cessation Self-Efficacy. Psychology and Addictive Behaviors. 2013, 71(1): 102-112.

38 White, K. M.; Smith, J. R.; Terry, D. J.; Greenslade, J. H.; McKimmie, B. M., supra note 7.

39 Kallgren, C. A.; Reno, R. R.; Cialdini, R. B., supra note 13.

40 Barriger, M.; Vélez-Blasini, C. J. Descriptive and Injunctive Social Norm Overestimation in Hooking Up and Their Role as Predictors of Hook-Up Activity in a College Student Sample. Journal of Sex Research. 2013, 50(1): 84-94. 
kad klausimų, konteksto ar eiliškumo efektai minètuose tyrimuose pasireiške ar kokiu nors būdu iškreipè jų rezultatus, tačiau privalu atkreipti dèmesị i tai, jog klausimų efektams ịvertinti ir aptarti socialinių normų tyrimuose nèra skiriama pakankamai dèmesio.

Šio tyrimo objektas yra klausimų eiliškumo efektai, pasireiškiantys užduodant klausimus, nukreiptus ị privalomąsias bei apsakomąsias socialines normas. Tyrimo tikslas yra išsiaiškinti klausimų eiliškumo efektų dèsningumus, pasireiškiančius tiriant šių skirtingų pobūdžių normas.

Keliamos šios hipotezės: 1) ị sąmonę iškèlus vienokio pobūdžio normas (pateikus $\mathfrak{i}$ jas orientuotus teiginius pirmiau), kitokio pobūdžio normų vertinimas (atsakymai ị vèlesnius teiginius) pakis; 2) apsakomųjų bei privalomųjų normų klausimus pateikus atsitiktine tvarka, eiliškumo efektai nebus stebimi.

\section{Tyrimo metodika}

Tiriamieji. Buvo pasirinkta patogioji imtis, kurią sudaro 191 studentas iš keleto Vilniaus aukštụjų mokyklų. Kokybiškai anketas užpildė 186 respondentai iš 191 apklaustujų̧. Iš kokybiškai užpildžiusių anketas - 92 vyrai, 85 moterys, 9 lyties nenurodè. Jauniausiems respondentams yra 18 metų, vyriausiam - 37 metai $(\mathrm{M}=20$ metų; $\mathrm{SD}=2$ metai), 7 respondentai amžiaus nenurodè.

Metodika. Tyrimui buvo parinkta 15 teiginių, nukreiptų $\mathfrak{i}$ socialines normas, teiginius parinko ir anketas sudare šio tyrimo autorius. Pasirinkti teiginiai orientuoti ị tautinị pakantumą, tikintis, jog ši tema pakankamai rezonuos su tyrimo dalyviais. Teiginiai buvo formuluojami dvejopai: vienu atveju orientuojant juos ị privalomąsias normas (pvz.: „Žmonèms derètų gerbti visų tautybių asmenis vienodai.“), kitu atveju - $\mathfrak{i}$ apsakomąsias (pvz.: „Dauguma žmonių gerbia visų tautybių asmenis vienodai.“). Klausimo turinys visada išlikdavo toks pat, keisdavosi tik normų pobūdis, ị kurị jis orientuotas. Buvo parengti trys tyrimo anketos variantai po trisdešimt klausimų: 1) pirmiausia pateikiant privalomąsias normas atspindinčius teiginius, po to - apsakomąsias; 2) pirmiausia pateikiant apsakomąsias normas atspindinčius klausimus, po to - privalomąsias; 3 ) teiginiai pateikiami atsitiktine tvarka (visose šios grupés anketose tokia pačia tvarka). Teiginiai visose anketose nebuvo atskiriami jokiu akivaizdžiu žymèjimu, jie visi buvo pateikiami vienoje lentelèje. Kaip iprasta normų tyrimuose, teiginiai buvo vertinami penkių punktų Likerto skalèje nuo „visiškai sutinku“ iki „visiškai nesutinku“. Anketoje buvo prašoma nurodyti amžių ir lyț, taip pat buvo pabrěžiamas anketos anonimiškumas.

Anketų skalių rezultatai skaičiuoti sudedant visų atsakymų skaitines reikšmes ir padalinant iš teiginių skaičiaus. Atsakymai galejo igauti vieną iš penkių skaitinių reikšmių, nuo 1 - „visiškai sutinku“, iki 5 - „visiškai nesutinku“. Mažesnis apsakomųjų normų skalès ịvertis rodo didesnị suvoktą visuomenės normų laikymąsi; mažesnis privalomųjų normų skalès ịvertis rodo griežtesnị visuomenės normų suvokimą. 
Atlikta visų trijų tipų anketų teiginių vidinio suderinamumo analizė atskleide், jog abiejų rūšių normų skalès rodo gerą suderinamumą visų trijų eksperimento grupių atveju. Anketose, kuriose pirmiausia buvo pateikiami ị apsakomąsias normas nukreipti teiginiai: privalomųjų normų (PN) skalès $\alpha=0,897$, apsakomųjų normų (AN) $\alpha=0,780$; pirmiausia pateikus teiginius, nukreiptus ị privalomąsias normas: $P N$ $\alpha=0,878$, AN $\alpha=0,785$; teiginius pateikus atsitiktine tvarka: PN $\alpha=0,857, \mathrm{AN}$ $\alpha=0,817$. Tokie rezultatai rodo, jog anketų skalès yra tinkamos tolesnei analizei.

Tyrimo eiga. Su tyrimo dalyviais buvo susitinkama paskaitų metu, jų buvo prašoma užpildyti pateiktas anketas. Dalyviai atsitiktinai gaudavo vieną iš trijų anketos variantų. Tyrimo dalyviai buvo informuojami, jog jie dalyvauja apklausoje apie socialines normas, jų buvo prašoma anketas pildyti nuoširdžiai ir nesižvalgyti, nesitarti ir netrukdyti kitiems pildantiems. Anketos pildymas trukdavo vidutiniškai septynias minutes. Buvo surinkta 191 anketa, iš jų 2 buvo sugadintos, 3 anketose buvo praleista daugiau nei 2 atsakymai, todèl šios anketos buvo pašalintos iš analizès. Anketose, kuriose buvo praleista ne daugiau nei 2 atsakymai, trūkstamos vertès buvo užpildomos vidutine skalès verte.

Dèl dalintų atsitiktinai sumaišytų tyrimo anketų, ir tam tikru lygiu - dèl sugadintų tyrimo anketų, susidarè nevienodo dydžio tyrimo grupès, tačiau visose tyrimo grupèse tiriamųjų amžiaus vidurkis yra 20 metų, standartinis nuokrypis lygus 2 metams. Taip pat tyrimo grupèse dalyviai panašiai pasiskirstę pagal lytį.

Duomenų skaičiavimas. Tyrimo duomenų statistinei analizei naudota GNU PSPP v0.7.9 statistinès analizès programa. Efekto dydžiai ( $\eta$ ir Coheno $d$ ) skaičiuoti pagal A. Fieldo ${ }^{41}$ pateiktas rekomendacijas. Visų trijų eksperimento grupių abiejų skalių skirstiniai statistiškai reikšmingai nesiskyrè nuo normaliojo skirstinio (tikrinta Šapiro ir Vilko (Shapiro-Wilk) testu, visais atvejais $\mathrm{p}>0,05$ ), todèl pasirinkta taikyti parametrinius statistinius kriterijus. Kadangi duomenys tenkino homogeniškumo sąlygą, hipotezèms tikrinti pasirinkta vienfaktorinè dispersinė analizè. Post hoc analizei pasirinktas konservatyvus Bonferroni testas, tuo siekta apsisaugoti nuo pirmo tipo klaidos galimybès.

\section{Rezultatai}

Siekiant patikrinti tyrimo hipotezes, buvo atlikta vienfaktorinè dispersinè analizė, kuria tikrinta, ar yra skirtumų tarp anketų skalių vidurkių skirtingose eksperimento grupėse. Skalių îverčių aprašomoji statistika pateikiama 1 lentelèje. 
1 lentelè. Normų skalių aprašomoji statistika

\begin{tabular}{llllll}
\hline & EG & N & M & SD & SE \\
\hline & PA & 59 & 2,73 & 0,47 & 0,06 \\
& PP & 53 & 3,06 & 0,45 & 0,06 \\
$\begin{array}{l}\text { Apsakomųjų normų skalès } \\
\text { rezultatai }\end{array}$ & AT & 74 & 2,81 & 0,49 & 0,06 \\
& Iš & 186 & 2,86 & 0,49 & 0,04 \\
& viso & & & & 0,08 \\
\hline & PA & 59 & 2,02 & 0,59 & 0,08 \\
\cline { 2 - 6 } & PP & 53 & 2,03 & 0,55 & 0,08 \\
$\begin{array}{l}\text { Privalomųjų normų skalès } \\
\text { rezultatai }\end{array}$ & AT & 74 & 1,82 & 0,45 & 0,05 \\
& Iš & 186 & 1,94 & 0,53 & 0,04 \\
& viso & & & & \\
\hline
\end{tabular}

Pastabos: EG - eksperimento grupé; PA - pirmiausia pateikiami teiginiai, nukreipti $\mathfrak{i}$ apsakomąsias normas; PP - pirmiausia privalomųjų normų teiginiai; AT - teiginiai išdèstyti atsitiktine tvarka; $\mathrm{N}$ - imties dydis; $\mathrm{M}$ - vidurkis; SD - standartinis nuokrypis; SE - standartine paklaida.

Dispersinè analizė atskleide், jog yra stebimas statistiškai reikšmingas klausimų eiliškumo efektas tiek apsakomųjų normų $(F(3,41)=7,15 ; \mathrm{p}<0,01 ; \eta=0,27)$, tiek privalomųjų normų $(\mathrm{F}(2,51)=3,42 ; \mathrm{p}<0,05 ; \eta=0,19)$ skalių atveju. Tokie rezultatai rodo, jog klausimų eiliškumas anketoje, tiriant apsakomąsias bei privalomąsias socialines normas, iš tiesų turi reikšmės gautiems rezultatams, tačiau efektai gana maži. Siekiant išsiaiškinti efektų kryptis, atlikta post hoc analizè. Saugantis nuo pirmo tipo klaidos, pasirinktas konservatyvus Bonferroni statistinis kriterijus, kadangi tyrimo rezultatai gali turèti metodologinių implikacijų normų tyrimams.

Post hoc analizè atskleide, jog eiliškumo efektai stebimi tik apsakomụjų normų skalès atveju (2 lentelè). Pirmiausia anketose pateikus teiginius, nukreiptus $\mathfrak{i}$ apsakomąsias normas, apsakomųjų normų skalès ịverčiai yra žemesni (rodantys didesnị suvoktą normų laikymąsi), nei pirmiau pateikus privalomųjų normų teiginius. Teiginius pateikus atsitiktine tvarka, apsakomųjų normų skalès rezultatai nesiskiria nuo grupès, gavusios anketas, kuriose pirmiausia pateikiami teiginiai, nukreipti į apsakomąsias normas, tačiau skiriasi nuo grupès, gavusios anketas, kuriose pirmiausia pateikiami teiginiai, nukreipti ì privalomąsias normas, rezultatų. 
2 lentelè. Normų skalių post hoc analizè, naudojant Bonferroni testą

\begin{tabular}{|c|c|c|c|c|c|}
\hline & \multicolumn{5}{|c|}{ Eksperimento grupè } \\
\hline & (I) & $(J)$ & $(\mathrm{I}-\mathrm{J})$ & SE & Cohen'o d \\
\hline \multirow{6}{*}{$\begin{array}{l}\text { Apsakomųjų normų } \\
\text { skalės rezultatai }\end{array}$} & \multirow{2}{*}{$\mathrm{PA}$} & $\mathrm{PP}$ & $-0,32^{\star *}$ & 0,09 & $-0,71$ \\
\hline & & AT & $-0,08$ & 0,08 & $-0,16$ \\
\hline & \multirow{2}{*}{ PP } & PA & $0,32^{\star *}$ & 0,09 & 0,71 \\
\hline & & AT & $0,25^{\star}$ & 0,09 & 0,52 \\
\hline & \multirow{2}{*}{ AT } & PA & 0,08 & 0,08 & 0,16 \\
\hline & & $\mathrm{PP}$ & $-0,25^{*}$ & 0,09 & $-0,52$ \\
\hline \multirow{6}{*}{$\begin{array}{l}\text { Privalomųjų normų } \\
\text { skalès rezultatai }\end{array}$} & \multirow{2}{*}{$\mathrm{PA}$} & $\mathrm{PP}$ & $-0,01$ & 0,10 & $-0,01$ \\
\hline & & AT & 0,20 & 0,09 & 0,39 \\
\hline & \multirow{2}{*}{ PP } & $\mathrm{PA}$ & 0,01 & 0,10 & 0,01 \\
\hline & & AT & 0,21 & 0,09 & 0,42 \\
\hline & \multirow{2}{*}{ AT } & $\mathrm{PA}$ & $-0,20$ & 0,09 & $-0,39$ \\
\hline & & $\mathrm{PP}$ & $-0,21$ & 0,09 & $-0,42$ \\
\hline
\end{tabular}

Pastabos: PA - pirmiausia pateikiami teiginiai, nukreipti i apsakomąsias normas; PP - pirmiausia privalomųjų normų teiginiai; AT - teiginiai išdèstyti atsitiktine tvarka; SE - standartiné paklaida.

${ }^{*} \mathrm{p}<0,05 ;{ }^{* *} \mathrm{p}<0,01$.

Privalomųjų normų skale pasirodè atspari eiliškumo efektams, statistiškai reikšmingų šios skalès vidurkio skirtumų tarp eksperimento grupių nebuvo rasta, tačiau, stebint 2 lentelejje pateiktus duomenis, galima pastebèti, jog efekto dydis tarp grupès, gavusios anketas, kuriose teiginiai buvo pateikti atsitiktine tvarka, rezultatu ir kitų dviejų eksperimento grupių rezultatų, yra žymiai didesnis nei efekto dydis tarp grupių, gavusių anketas, kuriose teiginiai buvo pateikiami blokais. Tai leidžia įtarti, jog, esant didesnei imčiai, eiliškumo efektai galètų išryškèti, tačiau jie nebūtų tokie žymūs, kaip apsakomųjų normų skalès atveju.

\section{Rezultatų aptarimas}

Tyrimas atskleidè, jog kartu pateikus i vienos rūšies normas orientuotus teiginius, sukuriamas kontekstas, kuriame vertinami vèlesni teiginiai. Tai patvirtina, jog, 
padarius tam tikrą informaciją labiau prieinamą ${ }^{42}$ bei sukūrus tam tikrą kontekstą ${ }^{43}$, galima susidurti su rezultatų iškraipymais. Pirmiau klausiant apie realią žmonių elgseną (apsakomosios normos), ši elgsena yra vertinama labiau teigiamai nei tuo atveju, kai pirmiau klausiama apie tai, kaip žmonèms derètų elgtis (privalomosios normos). Tais atvejais, kai privalomosios normos iškeliamos ị sąmonę i jas orientuotus klausimus pateikiant pirmiau, apsakomosios normos, kurių atspindys yra prisiminta žmonių elgsena, galimai yra vertinamos pagal ką tik įsisąmonintas privalomąsias normas, kurias gali būti sunku išpildyti. Taip pat toks klausimų eiliškumas gali būti suvokiamas kaip privalomųjų bei apsakomųjų normų priešprieša, o tai gali sukelti kontrasto tarp šių dalykų suvokimą.

Anketose teiginius pateikus atsitiktine tvarka, apsakomųjų normų vertinimai užèmè tarpinę poziciją tarp kitais dviem būdais gautų vertinimų. Tai rodo, jog privalomųjų normų įtaka apsakomųjų normų suvokimui buvo iš dalies neutralizuota, nes i sąmonę vienu metu buvo iškeliamos abiejų rūšių normos; nebuvo progos vienos ar kitos rūšies normoms būti labiau įsisąmonintoms ${ }^{45} 464748$. Stebimas dèsningumas leidžia teigti, jog, tiriant privalomąsias bei apsakomąsias socialines normas, nuo klausimų eiliškumo efektų galima iš dalies apsisaugoti anketose klausimus pateikiant ne blokais, bet atsitiktine tvarka.

Privalomosios normos pasirodė esančios atsparios eiliškumo efektams. Tai rodo, jog jų suvokimas veikiausiai yra gilesnis, stabilesnis. Vis dèlto derètų atkreipti dèmesị $\mathfrak{i}$ tai, jog efekto dydis tarp privalomųjų normų vertinimo vidurkių eksperimento grupèse nèra vienodas. Tais atvejais, kai anketose teiginiai buvo pateikiami blokais, gauti privalomųjų normų rezultatai yra daug panašesni vienas ị kitą nei tuo atveju, kai teiginiai buvo pateikiami atsitiktine tvarka. Statistinis reikšmingumas vertinant vidurkių skirtumus nebuvo pasiektas, todèl negalima kalbèti apie realių skirtumų egzistavimą, tačiau privalu paminèti, jog esami rezultatai rodo, jog konstruojant klausimynus normų tyrimuose reikètų atsižvelgti ir ị galimai egzistuojančius eiliškumo efektus privalomųjų normų atžvilgiu.

\section{Išvados ir rekomendacijos}

Aptikta, jog apsakomųjų normų vertinimai yra jautrūs klausimų eiliškumui, tačiau privalomųjų normų vertinimai yra gana atsparūs klausimų eiliškumui.

42 Auh, S.; Salisbury, L. C.; Johnson, M. D., supra note 31.

43 Willits, F. K.; Saltiel, J., supra note 30.

44 Scandell, D. J.; Wlazelek, B.; Bentelspacher, C. E.; Rees, K. S.; Thomas, S. L., supra note 32.

45 Griskevicius, V.; Cialdini, R. B.; Goldstein, N. J., supra note 12

46 Kallgren, C. A.; Reno, R. R.; Cialdini, R. B., supra note 13.

47 Melnyk, V. van Herpen, E.; Fischer, A. R. H.; van Trij, H. C. M., supra note 14.

48 Smith, J. R.; Louis, W. R., supra note 6. 
Anketose teiginius pateikus atsitiktine tvarka, eiliškumo efektai buvo iš dalies pašalinti.

Atliekant tyrimus, kuriuose yra pateikiami teiginiai, nukreipti i privalomąsias bei apsakomąsias socialines normas, rekomenduojame teiginius pateikti atsitiktine tvarka arba, jei negalima išvengti teiginių pateikimo blokais, rekomenduojame pirmiau pateikti teiginius, nukreiptus ị apsakomąsias normas.

\section{Literatūra}

Auh, S.; Salisbury, L. C.; Johnson, M. D. Order Effects in Customer Satisfaction Modeling. Journal of Marketing Management. 2003, 19(3-4).

Barriger, M.; Vélez-Blasini, C. J. Descriptive and Injunctive Social Norm Overestimation in Hooking Up and Their Role as Predictors of Hook-Up Activity in a College Student Sample. Journal of Sex Research. 2013, 50(1).

Baumgartner, S. E.; Valkenburg, P. M.;

Peter, J. The Influence of Descriptive and Injunctive Peer Norms on Adolescents' Risky Sexual Online Behavior. Cyberpsychology, Behavior, and Social Networking. 2011, 14(12).

Blair, E.; Sudman, S.; Bradburn, N. M.; Stocking, C. How to Ask Questions about Drinking and Sex: Response Effects in Measuring Consumer Behavior. Journal of marketing Research. 1977, 14(3).

Brauer, M.; Chaurand, N. Descriptive Norms, Prescriptive Norms, and Social Control: An Intercultural Comparison of People's Reactions to Uncivil Behaviors. European Journal of Social Psychology. 2010, 40(3).

Chan, J. C. Response-Order Effects in Likert-Type Scales. Educational and Psychological Measurement. 1991, 51.

Christian, L. M.; Dillman, D. A. The Influence of Graphical and Symbolic Language Manipulations on Responses to Self- Administered Questions. The Public Opinion Quarterly. 2004, 68(1).

Cialdini, R. B.; Reno, R. R.; Kallgren, C. A. A Focus Theory of Normative Conduct: Recycling the Concept of Norms to Reduce Littering in Public Places. Journal of Personality and Social Psychology. 1990, 58(6).

Croson, R.; Handy, F.; Shang, J. Keeping Up With the Joneses. The Relationship of Perceived Descriptive Social Norms, Social Information, and Charitable Giving. Nonprofit Management \& Leadership. 2009, 19(4).

FeldmanHall, O.; Mobbs, D.; Evans, D.; Hiscox, L.; Navrady, L.; Dalgleish, T. What We Say and What We Do: The Relationship Between Real and Hypothetical Moral Choices. Cognition. 2012, 123(3).

Field, A. Discovering Statistics Using SPSS. London: SAGE Publications, 2006

Gerber, A. S.; Rogers, T. Descriptive Social Norms and Motivation to Vote: Everybody's Voting and so Should You. The Journal of Politics. 2009, 71(1).

Griskevicius, V.; Cialdini, R. B.; Goldstein, N. J. Social Norms: An Underestimated and Underemployed Lever for Managing Climate Change. International Journal of Sustainability Communication. 2008, 3.

Holbrook, A. L.; Krosnick, J. A.; Moore, D.; Tourangeau, R. Response Order Effects in Dichotomous Categorical 
Questions Presented Orally. The Impact of Question and Respondent Attributes. Public Opinion Quarterly. 2007, 71(3).

Kallgren, C. A.; Reno, R. R.; Cialdini, R. B. A Focus Theory on Normative Conduct: When Norms Do and Do Not Affect Behavior. Personality and Social Psychology Bulletin. 2000, 26(8).

Kebbell, M. R.; Evans, L.; Johnson, S. D. The Influence of Lawyers' Questions on Witness Accuracy, Confidence, and Reaction Times and on Mock Jurors' Interpretation of Witness Accuracy. Journal of Investigative Psychology and Offender Profiling. 2010, 7(3).

Larimer, M. E.; Neighbors, C. Normative Misperception and the Impact of Descriptive and Injunctive Norms on College Student Gambling. Psychology of Addictive Behaviors. 2003, 17(3).

Larimer, M. E.; Turner, A. P.; Mallett, K. A.; Geisner, I. M. Predicting Drinking Behavior and Alcohol-Related Problems Among Fraternity and Sorority Members: Examining the Role of Descriptive and Injunctive Norms. Psychology of Addictive Behavior. 2004, 18(3).

McDermott, M. L.; Frankovic, K. A. The Polls - Review. Horserace Polling and Survey Method Effects: An Analysis of the 2000 Campaign. Public Opinion Quarterly. 2003, 67(2).

Melnyk, V.; van Herpen, E.; Fischer, A. R. H.; van Trij, H. C. M. To Think of not to Think: The Effect of Cognitive Deliberation on the Influence of Injunctive Versus Descriptive Social Norms. Psychology \& Marketing. 2011, 28(7).

Neighbors, C.; Geisner, I. M.; Lee. C. M. Perceived Marijuana Norms and Social Expectancies Among Entering College Student Marijuana Users. Psychology of Addictive Behaviors. 2008, 23(3).
Phua, J. J. The Reference Group Perspective for Smoking Cessation: An Examination of the Influence of Social Norms and Social Identification With Reference Groups on Smoking Cessation SelfEfficacy. Psychology and Addictive Behaviors. 2013, 71(1).

Ramirez, I. L.; Straus, M. A. The Effect of Question Order on Disclosure in Intimate Partner Violence: An Experimental Test Using the Conflict Tactics Scales. Journal of Family Violence. 2006, 21(1).

Reno, R. R.; Cialdini, R. B.; Kallgren, C. A. The Transsituational Influence of Social Norms. Journal of Personality and Social Psychology. 1993, 64(1).

Scandell, D. J.; Wlazelek, B.; Bentelspacher, C. E.; Rees, K. S.; Thomas, S. L. Effects of Questionnaire Order on Self-Reported Sexual Behavior, Risk Perceptions, and Ratings of HIV and STD Protection Strategies. Journal of Psychology \& Human Sexuality. 2003, 15(1).

Schröder, T.; Thagard, P. The Affective Meanings of Automatic Social Behaviors: Three Mechanismz That Explain Priming. Psychological Review. 2013, 120(1).

Schwarz, N.; Hippler, H-J. Subsequent Questions May Influence Answers to Preceding Questions in Mail Surveys. The Public Opinion Quarterly. 1995, 59(1).

Siminski, P. Order Effects in Batteries of Questions. Quality \& Quantity. 2008, 42(4).

Smith, J. R.; Louis, W. R. Do as We Say and as We Do: The Interplay of Descriptive and Injunctive Group Norms in the Attitude-Behaviour Relationship. British Journal of Social Psychology. 2008, 47(4).

White, K. M.; Smith, J. R.; Terry, D. J.; Greenslade, J. H.; McKimmie, B. M. Social Influence in the Theory of Planned Behaviour: The Role of Descriptive, Injunctive, and In-Group 
Norms. British Journal of Social Psychology. 2009, 48(1).

Willits, F. K.; Saltiel, J. Question Order

Effects on Subjective Measures of

Quality of Life. Rural Sociology. 1995, 60(4).
Yang, S.; Wyckoff, L. A. Perceptions of Safety and Victimization: Does Survey Construction Affect Perceptions? Journal of Experimental Criminology. 2010, 6(3).

\title{
QUESTION ORDER EFFECTS IN EVALUATING INJUNCTIVE AND DESCRIPTIVE SOCIAL NORMS
}

\author{
Mykolas Simas Poškus \\ Mykolas Romeris University, Lithuania
}

Summary. Studies that involve measurements of social norms via questionnaires often do not take possible question order effects into consideration. This study aims to uncover the order effects that occur while measuring injunctive and descriptive social norms via questionnaires. For this purpose, three 30 item questionnaires were constructed, the only difference between them being the order of the items presented. In the first type of questionnaire, items directed at injunctive norms were presented first; in the second - items directed at descriptive norms were presented first; lastly, in the third type of questionnaire, items were presented in random order. One way analysis of variance was used to determine whether order effects were present. It was hypothesized that when norms of one type are made salient, norms of the other type would be perceived differently than if they were presented first. It was also hypothesized that order effects would not be present when questionnaire items were presented in random order.

Results of this study have shown that reported descriptive norms can be influenced by the order of presented questions: when injunctive norm items are presented first, descriptive norms tend to be viewed as more distant from injunctive norms. Injunctive norms, however, appear more resistant to order effects and their position in the questionnaire appears to have no significant effect on their perception. Order effects were neutralized when questionnaire items were presented in random order.

Based on these findings, the authors recommend to researchers, who intend on measuring descriptive and injunctive social norms, to present questionnaire items in random order, in order to minimize the possible question order effects.

Keywords: descriptive norms, injunctive norms, question order. 
Mykolas Simas Poškus, Mykolo Romerio universiteto Socialinių technologijų fakulteto Psichologijos instituto doktorantas. Moksliniai interesai: evoliucinė psichologija, socialinė psichologija, aplinkos psichologija, tvari elgsena, tyrimų metodologija.

Mykolas Simas Poškus, Mykolas Romeris University, Faculty of Social Technologies, Institute of Psychology, $\mathrm{PhD}$ student. Research interests: evolutionary psychology, social psychology, environmental psychology, sustainable behavior, research methods. 